\title{
COMPARATIVE DIAGNOSTIC STUDY ON BREAST LESIONS
}

\author{
Anandi Andappan1, Bakthavatsalam Sathyapriya ${ }^{2}$ \\ ${ }^{1}$ Associate Professor, Department of General Surgery, Government Thoothukudi Medical College. \\ ${ }^{2}$ Associate Professor, Department of General Surgery, Government Thoothukudi Medical College.
}

ABSTRACT

\section{BACKGROUND}

The aim of the study is to evaluate the breast lumps using ultrasound and mammogram independently and in combination.

\section{METHODS}

In this study group there were 30 patients, out of whom 29 were female and one male patient. They presented with breast symptoms such as palpable lumps, breast pain and nipple discharge. They were examined prospectively over a period of six months. After examining with both the methods, FNAC correlation was done with each method.

\section{RESULTS}

In this study the sensitivity of the mammogram is $95 \%$ in detecting lesions and the specificity is $67 \%$ giving an accuracy of $90 \%$; the sensitivity of USG is $90 \%$ and specificity is only $40 \%$ giving an accuracy of $70 \%$. Cytology has a sensitivity of $85 \%$ and specificity of $50 \%$ and the accuracy is $77 \%$. With the combined modality, the sensitivity is $96 \%$ and the specificity is $83 \%$ and accuracy is $94 \%$. The study concludes that the sensitivity is increased when both the modalities are used in conjunction and with a needle biopsy it achieves a satisfactory specificity and it avoids unnecessary benign surgical biopsies.

\section{KEYWORDS}

Mammogram, Ultrasonogram, FNAC, HPE.

HOW TO CITE THIS ARTICLE: Andappan A, Sathyapriya B. Comparative diagnostic study on breast lesions. J. Evolution Med. Dent. Sci. 2016;5(28):1438-1444, DOI: 10.14260/jemds/2016/338

\section{INTRODUCTION}

The breast or mammary gland is a distinguishing feature of the class mammalia. From puberty to death, the breast is subjected to constant physical and physiological alterations that are related to menstruation, pregnancy, gestation and menopause. The impact of breast disease assumes greater importance as the incidence of breast cancer continues to increase steadily. ${ }^{1,2}$ Interest in the knowledge about breast diseases, esp. Breast cancer has increased greatly in recent years. Increasing public awareness of routine self-examination of breast has facilitated early detection of breast lesions. The use of mammography to screen asymptomatic women of 40 yrs. of age and over has been shown to detect breast cancer in the very early stages and consequently has reduced the mortality.,3 rates by 20 to 30 percent. Mammography is the only effective technique employed in screening of breast carcinoma. As the patient with a breast symptom attends the breast clinic, a careful history is recorded. The duration of symptoms, fluctuation with menstrual cycle is assessed.

Inspection and palpation of the breast is done in all positions and followed by examination of axillary and supraclavicular regions. Both breasts are examined thoroughly. Although numerous advantages and improvements in mammography have occurred within the last few decades and has greatly improved image quality, the technique is not without shortcomings resulting in limitation in the sensitivity and specificity of this imaging modality.

Financial or Other, Competing Interest: None.

Submission 18-02-2016, Peer Review 14-03-2016,

Acceptance 19-03-2016, Published 07-04-2016.

Corresponding Author

Dr. Anandi Andappan,

C. 25, Annanagar East, $8^{\text {th }}$ Street,

Chennai-600102, Tamilnadu.

E-mail: anandiandappan2003@yahoo.com

DOI: $10.14260 /$ jemds/2016/338
The use of ultrasonogram in evaluation of breast lesions has its own place, especially in young females. ${ }^{4,5}$ and in individuals with small breasts. Neither clinical nor imaging modality alone can detect breast cancers with certainty. To achieve an effective result, all the clinical and imaging modalities are to be done in conjunction with FNAC or HPE. With more emphasis being placed on early detection of cancer breast and breast conservation surgery, the relative merits of ultrasonogram and mammogram with FNAC correlation should be carefully evaluated. This study aims at comparing the effectiveness of mammography, ultrasonography and FNAC and to understand the efficacy of evaluation using the three modalities in combination in managing breast lesions.

\section{AIM}

The aim of the study is to evaluate the breast lumps using ultrasound and mammogram independently and in combination.

\section{MATERIALS AND METHODS}

In this study group there were 30 patients, out of whom 29 were female and one male patient. They presented with breast symptoms such as palpable lumps, breast pain and nipple discharge. They were examined prospectively over a period of six months. All patients were evaluated using all the three methods, but there were a few technically difficult situations because of the small sized breast.

\section{Clinical Examination}

Of the 30 patients evaluated 7 patients were less than 30 years, 10 patients were between 31 to 40 years, 5 patients were between 40 to 50 years, 5 patients between 51 to 60 years, 3 patients were more than 60 years as given below in the table. These patients were examined clinically and were found to have either solid or cystic masses. 
Few patients also had nipple discharge. All patients were given adequate explanation about the procedure and consent was obtained.

\section{Equipment}

Mammography was performed in a dedicated mammographic unit. It has a radiographic stand to radiograph the patient in both standing and sitting posture in combination with mammographic X-ray tube assembly with compression paddle. The cassette used for mammogram was KODAK min 30 $\mathrm{R}$ with single-sided screen with ultrasensitive films with emulsion coated on single side. Patients submitted for mammogram were positioned for craniocaudal and mediolateral oblique views of the breast. For MLO view, the tube and the cassette were angulated between 45 to 60 degrees.

Ultrasonogram was performed on $\mathrm{F}$ sonic real time scanner with hand-held linear electronic array transducer. The transducer could be operated in the frequency range of 7.5 $\mathrm{MHz}$ and was provided with a built-in fluid offset.
For USG, patients were positioned in supine with hands held above their heads. FNAC was done with a $10 \mathrm{cc}$ disposable syringe with a 23 or $24 \mathrm{G}$ needle. Smear was made and cells were air dried. FNAC was done in lying position. Nipple discharge was squeezed and applied over a slide and sent for cytological studies.

\section{RESULTS}

\begin{tabular}{|c|c|}
\hline Age Group & No. of Patients \\
\hline Below 30 Years & 7 \\
\hline $31-40$ Years & 10 \\
\hline 41-50 Years & 5 \\
\hline 51-60 Years & 5 \\
\hline$>60$ Years & 3 \\
\hline
\end{tabular}

\begin{tabular}{|c|c|}
\hline Sex of the Patient & No. of Patients \\
\hline Female & 29 \\
\hline Male & 1 \\
\hline \multicolumn{2}{|c|}{ Sex Distribution } \\
\hline
\end{tabular}

\begin{tabular}{|c|c|c|c|c|c|c|}
\hline $\begin{array}{c}\text { Unilateral/ } \\
\text { Bilateral }\end{array}$ & $\begin{array}{c}\text { Location } \\
\text { of } \\
\text { Mass }\end{array}$ & Consistency & $\begin{array}{c}\text { Skin } \\
\text { Thickening }\end{array}$ & $\begin{array}{c}\text { Nipple } \\
\text { Retraction }\end{array}$ & Nodes & $\begin{array}{c}\text { Opposite } \\
\text { Breast }\end{array}$ \\
\hline All & LUO-6 & CYSTIC-1 & One & Seven & AXILLARY NODES & Normal \\
Unilateral & LUI-8 & SOFT-1 & & & BILATERAL-NIL \\
& LLO-2 & FIRM-17 & & & \\
& LLI-1 & HARD-4 & & & \\
& RUO-2 & & & & \\
& RUI-2 & & & & \\
& RLO-2 & & & \\
& CENT-2 & & & \\
\hline
\end{tabular}

The masses were overlapping the quadrants in few cases. Regarding the consistency, some had variable consistency like frim to hard.

\begin{tabular}{|c|c|c|c|c|}
\hline Nature & $\mathbf{2 ~ c m}$ & $\mathbf{2 - 5} \mathbf{~ c m}$ & $\mathbf{5 ~ c m}$ & Total \\
\hline Benign & 4 & 7 & 2 & 13 \\
\hline Malignant & \multicolumn{5}{|c|}{ Size of the Mass } & 5 & 9 \\
\hline \multicolumn{4}{|c|}{} \\
\hline
\end{tabular}

The masses were separated according to the size and its histopathological correlation was analysed. It was observed that out of the total HPE proved and accurately measured masses, 4 were less than $2 \mathrm{~cm}$ in size and they were benign; 7 were in 2-5 cm range and was benign and 2 were over $5 \mathrm{~cm}$ and found to be benign. Majority of cases were in 2 to $5 \mathrm{~cm}$ group. Nine cases were malignant and 5 were in the $5 \mathrm{~cm}$ group.

\begin{tabular}{|c|c|c|c|}
\hline Pattern & Benign & Malignant & Total \\
\hline Dense & 5 & - & 5 \\
\hline Mixed & 9 & 9 & 18 \\
\hline Fatty & 4 & 1 & 5 \\
\hline \multicolumn{4}{|c|}{ Density of the Mass } \\
\hline
\end{tabular}

\begin{tabular}{|c|c|}
\hline Types of Discharge & No. of Patients \\
\hline Serous & 5 \\
\hline Milky & 2 \\
\hline Blood Stained & 1 \\
\hline \multicolumn{2}{|c|}{ Nipple Discharges } \\
\hline
\end{tabular}

One patient who had blood stained discharge showed evidence of duct ectasia on ductogram. Rest of the cases had normal mammographic findings corresponding to the age.

\section{Distribution of Malignancy}

Of the 30 cases analysed, 11 were found to be malignant with HPE correlation.

Categorization of malignant cases according to the age group was done.

\begin{tabular}{|c|c|c|}
\hline Age Group (Years) & Frequency & Percentage \\
\hline$<30$ Years & 0 & 0 \\
\hline $31-40$ Years & 2 & $18 \%$ \\
\hline $41-50$ Years & 5 & $46 \%$ \\
\hline $51-60$ Years & 2 & $18 \%$ \\
\hline$>60$ Years & 2 & $19 \%$ \\
\hline Total & $\mathbf{1 1}$ & $\mathbf{1 0 0} \%$ \\
\hline
\end{tabular}

The age group distribution of malignancy corresponds well with WHO statistics, i.e. about $77 \%$ of women with newly diagnosed cancer breast belonged to over the age of 40 years and cancer breast is relatively rare in women between 20-24 years of age. 
MAMMOGRAPHIC FINDINGS

\begin{tabular}{|c|c|c|c|c|c|c|c|c|c|c|c|}
\hline$\stackrel{\mathscr{0}}{\mathscr{E}}$ & 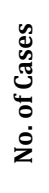 & 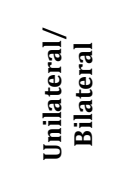 & 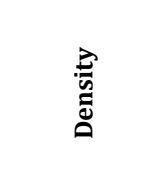 & 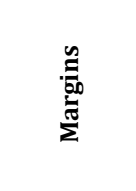 & 苞 & $\frac{\grave{\Xi}}{\grave{E}}$ & 웊 & 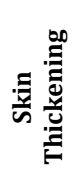 & 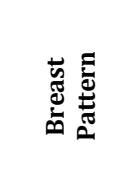 & 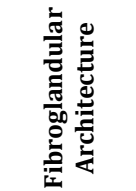 & 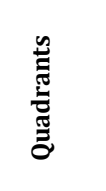 \\
\hline Fibroadenosis & 7 & Bilateral & Increased & Diffuse & & Single & + & - & - & $\begin{array}{c}\text { Diffusely } \\
\text { Dense }\end{array}$ & $\begin{array}{l}\text { Uo ui } \\
\text { Lo.li }\end{array}$ \\
\hline Fibroadenoma & 3 & Bilateral & $\begin{array}{l}\text { Increased } \\
\text { Round } \\
\text { Oval } \\
\text { Lobulated } \\
\end{array}$ & $\begin{array}{c}\text { Well } \\
\text { Defined }\end{array}$ & & Single & ++ & - & $\begin{array}{c}\text { Mixed } \\
\text { Glandular }\end{array}$ & $\begin{array}{c}\text { No } \\
\text { Distortion }\end{array}$ & $\begin{array}{l}\text { Uo ui } \\
\text { Lo li }\end{array}$ \\
\hline Infection & 2 & Unilateral & Increased & Diffuse & & Single & - & - & $\begin{array}{c}\text { Mixed } \\
\text { Glandular }\end{array}$ & $\begin{array}{c}\text { No } \\
\text { Distortion }\end{array}$ & Uo \\
\hline Malignancy & 10 & Unilateral & $\begin{array}{l}\text { Asymmetry } \\
\text { Increased } \\
\text { Density }\end{array}$ & Irregular & $\begin{array}{c}\text { Micro } \\
\text { Calcification }\end{array}$ & Single & - & + & $\begin{array}{l}\text { Mixed } \\
\text { Fatty }\end{array}$ & Distorted & $\begin{array}{c}\text { Uo lo } \\
\text { Ui li } \\
\text { Retro } \\
\text { Areolar }\end{array}$ \\
\hline $\begin{array}{l}\text { Cystosarcoma } \\
\text { Phyllodes }\end{array}$ & 1 & Unilateral & Hyperdense & $\begin{array}{c}\text { Irregular } \\
\text { Lobulated }\end{array}$ & & Single & - & - & Mixed & Distorted & $\begin{array}{c}\text { Uo lo } \\
\text { Ui li }\end{array}$ \\
\hline Duct Ectasia & 1 & Unilateral & & & & & & & & & $\begin{array}{c}\text { Retro } \\
\text { Areolar }\end{array}$ \\
\hline
\end{tabular}

\section{ULTRASONOGRAM FINDINGS}

\begin{tabular}{|c|c|c|c|c|c|c|c|c|c|c|}
\hline 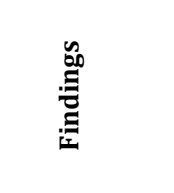 & 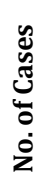 & 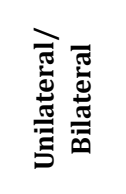 & 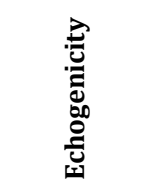 & 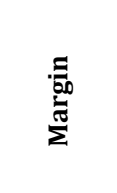 & : & 总泀 & 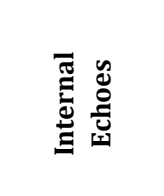 & 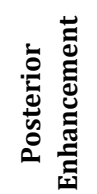 & 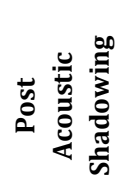 & 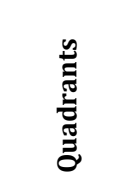 \\
\hline $\begin{array}{c}\text { Fibrocystic } \\
\text { Disease }\end{array}$ & 7 & Bilateral & Нypoechoic & Diffuse & - & Single & - & 7 & $\begin{array}{c}\text { Diffusely } \\
\text { Dense }\end{array}$ & \\
\hline Fibroadenoma & 3 & Unilateral & Hypoechoic & $\begin{array}{c}\text { Well } \\
\text { Defined }\end{array}$ & - & Single & - & & & Uo ui \\
\hline Infection & 1 & Unilateral & Hypoechoic & $\begin{array}{c}\text { Well } \\
\text { Defined }\end{array}$ & 1 & Single & $\begin{array}{c}\text { With } \\
\text { Internal } \\
\text { Echoes }\end{array}$ & & 1 case & Uo \\
\hline Malignancy & 11 & Unilateral & $\begin{array}{c}\text { Mixed } \\
\text { Echogenic }\end{array}$ & Irregular & 2 & Single & $\begin{array}{c}\text { With } \\
\text { Internal } \\
\text { Echoes } \\
\text { Degenerative } \\
\text { Changes }\end{array}$ & 2 cases & 9 cases & $\begin{array}{c}\text { All } \\
\text { Quadrants }\end{array}$ \\
\hline
\end{tabular}

\section{Comparative Analysis of Imaging Modality}

On analysis with the above data, it was found that combined modality was $100 \%$ in diagnosing fibrocystic disease, fibroadenoma and intramammary lymph node.

\begin{tabular}{|c|c|c|c|c|}
\hline Findings & $\begin{array}{c}\text { No. of } \\
\text { Cases }\end{array}$ & Mammogram & $\begin{array}{c}\text { Ultra- } \\
\text { sonogram }\end{array}$ & Combined \\
\hline $\begin{array}{c}\text { Fibrocystic } \\
\text { Disease }\end{array}$ & 7 & 7 & 7 & $100 \%$ \\
\hline Infection & 1 & 1 & 3 & $100 \%$ \\
\hline $\begin{array}{c}\text { Fibroaden } \\
\text { oma }\end{array}$ & 3 & 3 & 11 & $<$ Than \\
\hline $\begin{array}{c}\text { Carcinoma } \\
\text { Cystosarco } \\
\text { ma } \\
\text { Phyllodes }\end{array}$ & 11 & 10 & - & $100 \%$ \\
\hline $\begin{array}{c}\text { Intra } \\
\text { mammary } \\
\text { Lymph } \\
\text { node }\end{array}$ & 1 & 1 & 1 & $100 \%$ \\
\hline
\end{tabular}

\begin{tabular}{|c|c|}
\hline Fibrocystic Disease & 7 \\
\hline Infection & 1 \\
\hline Fibroadenoma & 3 \\
\hline Cystosarcoma Phyllodes & 1 \\
\hline Galactorrhoea & 1 \\
\hline Duct Ectasia & 1 \\
\hline Lymph Node & 1 \\
\hline Eczema & 1 \\
\hline $\begin{array}{c}\text { In this Study there were 16 } \\
\text { Cases with Benign Breast Diseases }\end{array}$ \\
\hline
\end{tabular}

The benign masses showed calcifications. These calcifications help us for determining the nature of the neoplastic process. The malignant calcifications are micro calcifications occurring in clusters with pleomorphism. Benign calcifications are picked up by ultrasonogram.

\begin{tabular}{|c|c|c|c|}
\hline & Mammogram & Ultrasonogram & Both \\
\hline Malignant & 6 & 2 & 8 \\
\hline Benign & 2 & 1 & 3 \\
\hline Table showing the Comparative Analysis of Mammogram and \\
Ultrasonogram in Picking up Calcifications \\
\hline
\end{tabular}




\section{Evaluation of Lymph Node Status}

Evaluation of lymph node is essential in staging the disease. Lymph nodes evaluation done by clinical methods, ultrasound and by mammogram.

\begin{tabular}{|c|c|}
\hline Clinical & 10 \\
\hline Ultrasonogram & 9 \\
\hline Mammogram & 1 \\
\hline
\end{tabular}

Lymph nodal disease evaluation is better with ultrasonogram. Mammogram identifies intramammary lymph node.

\section{DISCUSSION}

The comparative evaluation of breast mass by mammogram, ultrasonogram and FNAC reveals that combined approach of these modalities claim superiority over the single modality when used alone. $6,7,8$

\section{Fibrocystic Disease}

Seven cases were picked up by mammogram and six by ultrasonogram. A case sclerosing adenosis was suspected in mammogram and it was confirmed by HPE. By combined approach, all the cases were identified. Another case of diffuse lump was identified, where a malignancy could not be excluded. But ultrasonogram showed evidence of a tiny cyst surrounded by echogenic fibrous tissue. This is in accordance with the observation of Rosner that ultrasonogram provides a better description of lesions in fibrocystic disease. Hence, suspicious malignant cases can be easily differentiated with ultrasound and HPE. In another case where it was suspected clinically to be malignant, but ultrasonogram and mammogram confirmed it as infective pathology. In this chronic abscess, mammogram had a picture of a mass. Ultrasound showed evidence of an abscess as evidenced by the cystic nature of the swelling with internal echoes with posterior acoustic enhancement. Abscess can mimic as malignancy in mammogram, but with USG and FNAC this can be diagnosed correctly.

\section{Fibroadenoma}

Out of the total 3 cases both the modalities were able to identify the lesions and it was confirmed by FNAC/HPE. On USG, most of the fibroadenoma are either oval or lobulated. They had a smooth contour, weak internal echoes and uniform echo distribution. There is no post acoustal shadowing, because there was no calcification in a fibroadenoma.

\section{Cysts}

In this study, there was no case of any cystic lesions. There were cystic changes in a solid lesion. Ultrasound was better in identifying the cystic lesion and solid lesion as they are better delineated.

\section{Carcinoma}

Out of the 11 cases of carcinoma in this series mammogram was useful in diagnosing 10 cases, but ultrasonogram was able to identify all the 11 cases. HPE confirmed as malignancy in all cases; $100 \%$ accuracy was achieved in this study for diagnosing malignancy in combined modality. In one case mammogram was not able to identify the malignancy because an adequate compression could not be given due to large size mass. Ultrasound was able to identify calcification in 2 cases. Axillary lymph nodes was documented in ultrasonogram in 9 cases. Mammogram was not used to identify axillary disease.

\section{Cystosarcoma Phyllodes}

The only case of phyllodes tumour was diagnosed by mammogram. It was diagnosed based on large size, smooth contours and increased density. Ultrasound showed a lobulated mass with smooth contours with areas of cystic change, which had posterior acoustic enhancement.

\section{Nipple Discharge}

Out of the 8 cases with nipple discharge 5 had serous, 2 had milky discharge and 1 had blood stained discharge. One case had a Duct Ectasia, which was documented with ductogram. Another patient with nipple discharge showed areas of architectural distortion, but ultrasonogram and cytology were not positive for malignancy. HPE was also not positive. She is under close observation.

\section{Intramammary Lymph Node}

In one case, mammogram was helpful in identifying an intramammary lymph node. On ultrasound, she had axillary adenitis. HPE proved to be Tuberculosis.

\section{FNAC}

In this study, the role of cytology was helpful in documenting malignancy. Out of the 11 cases of malignancy, cytology was helpful in documenting malignancy in all the cases giving it $100 \%$ accuracy; 8 cases were diagnosed in the first sitting itself, rest required a second try. Trucut biopsy was done and HPE confirmation was done. In the benign cases, a case of sclerosing adenosis was diagnosed by Trucut biopsy alone. Abscess was diagnosed by the presence of inflammatory cells. Cystosarcoma phyllodes was diagnosed by Trucut biopsy.

In this study, not a single case of malignancy was below 30 years of age. Hence to conclude that ultrasound may be solely employed as the first modality in evaluating symptomatic breast in women less than 30 years of age, it was observed that mammogram showed a decreased diagnostic accuracy in young patients due to the dense nature of the breast. Ultrasonogram can identify lumps much more easily in the dense breasts. In elderly patients with fatty breasts, however, mammogram is a better diagnostic procedure as lumps stand out against the homogeneous ground-glass breast in mixed glandular pattern of breast. Though a definitive diagnosis is possible with non-invasive imaging procedures, for most lesions biopsy/fine needle aspiration cytology are essential for obtaining reliable results.6-8 Patients with palpable breast masses commonly present for imaging evaluation. Unfortunately, false-negative mammographic findings in the setting of a palpable breast mass have been estimated between $4 \%$ and $12 \% .{ }^{9-10}$ Therefore, malignancy cannot be excluded when mammographic findings of a palpable mass are negative. Mammogram can help physicians determine whether a lesion is potentially malignant and also screen for occult disease in the surrounding tissue.11,12-13 It was found from the literatures that mammogram is a wellestablished diagnostic modality for the breast. It has high diagnostic yield, but is not $100 \%$ accurate. ${ }^{14-15}$ Mammogram when combined with USG can yield significant improvement in accuracy rates. 


\section{Limitation}

\begin{tabular}{|c|c|}
\hline MAMMOGRAM & ULTRASONOGRAM \\
\hline $\begin{array}{c}\text { Solid and Cystic Masses Cannot } \\
\text { be Differentiated }\end{array}$ & Operator Dependent \\
\hline $\begin{array}{c}\text { Intracystic Lesions Cannot be } \\
\text { Diagnosed }\end{array}$ & $\begin{array}{c}\text { Isoechoic Masses May } \\
\text { be Missed Especially } \\
\text { when Small }\end{array}$ \\
\hline $\begin{array}{c}\text { Young Breast have Dense } \\
\text { Fibroglandular Parenchyma } \\
\text { and Obscure Masses }\end{array}$ & $\begin{array}{c}\text { Microcalcification may } \\
\text { not be Identified }\end{array}$ \\
\hline $\begin{array}{c}\text { Fibrocystic Disease Masks the } \\
\text { Margin of a Benign Lump }\end{array}$ & $\begin{array}{c}\text { Circumscribed } \\
\text { Labcinoma may be } \\
\text { Labed as Benign }\end{array}$ \\
\hline $\begin{array}{c}\text { Abscess and Tuberculosis may } \\
\text { Mimic Carcinoma }\end{array}$ & $\begin{array}{c}\text { Multicentric Carcinoma } \\
\text { may be Missed }\end{array}$ \\
\hline $\begin{array}{c}\text { Evaluation of Small Tender } \\
\text { Breasts is Difficult and } \\
\text { Inadequate }\end{array}$ & \\
\hline $\begin{array}{c}\text { Lactating and Pregnant Patients } \\
\text { cannot be Evaluated }\end{array}$ & \\
\hline
\end{tabular}

\section{Advantages}

\begin{tabular}{|c|c|}
\hline MAMMOGRAM & ULTRASONOGRAM \\
\hline $\begin{array}{c}\text { Microcalcification Can be Seen } \\
\text { Well }\end{array}$ & $\begin{array}{c}\text { Solid and Cystic Masses are } \\
\text { Differentiated }\end{array}$ \\
\hline $\begin{array}{c}\text { Multicentric Carcinoma Can be } \\
\text { Picked Up }\end{array}$ & $\begin{array}{c}\text { Young Breast with Dense } \\
\text { Fibroglandular Parenchyma are } \\
\text { Easily Diagnosed }\end{array}$ \\
\hline $\begin{array}{c}\text { Characteristics of Mass are } \\
\text { Better Defined }\end{array}$ & $\begin{array}{c}\text { Contour of Mass Better } \\
\text { Visualised Even in the Presence } \\
\text { of Adenosis }\end{array}$ \\
\hline & $\begin{array}{c}\text { Tender and Small Breasts Can } \\
\text { Be Evaluated Better }\end{array}$ \\
\hline & Abscess are Better Defined \\
\hline & $\begin{array}{c}\text { Pregnant Patients are } \\
\text { Examined Safely }\end{array}$ \\
\hline
\end{tabular}

\section{Cytology}

Cytological studies are used to determine the type of lesions and malignancy can be identified with $100 \%$ efficacy. In benign cases a few lesions were difficult to diagnose, wherein a Trucut needle biopsy was necessary.

\section{Evaluation of the Study}

The Following Measures were used to Evaluate the Study

1. Sensitivity: It is the ability of a test to identify correctly all those who have the disease.

2. Specificity It is the ability of a test to identify correctly those who do not have the disease.

3. Predictive Accuracy: In addition to sensitivity and specificity, the performance of the test is measured by its predictive value which reflects the diagnostic power of the test. The predictive accuracy depends on the sensitivity, specificity and disease prevalence.

The predictive value of a positive test indicates the probability that a patient with positive result has in fact the disease in question. The more prevalence a disease in a given population, the more accurate will be the predictive value of positive screening test. The predictive value of a positive result falls as disease prevalence declines.

\section{Comparative Analysis}

1. Sensitivity $a / a+c X 100$ True Positive

2. Specificity $d / b+d X 100$ True Negative
3. Positive Predictive Value. $a / a+b X 100$

4. Negative Predictive Value. $d / d+c$ X 100

5. Accuracy $\mathrm{a}+\mathrm{d} / \mathrm{N}$

It is the sum of true positives and false negatives by the total number of cases evaluated

6. Prevalence $\mathrm{a}+\mathrm{c} / \mathrm{N}$

Comparative Analysis

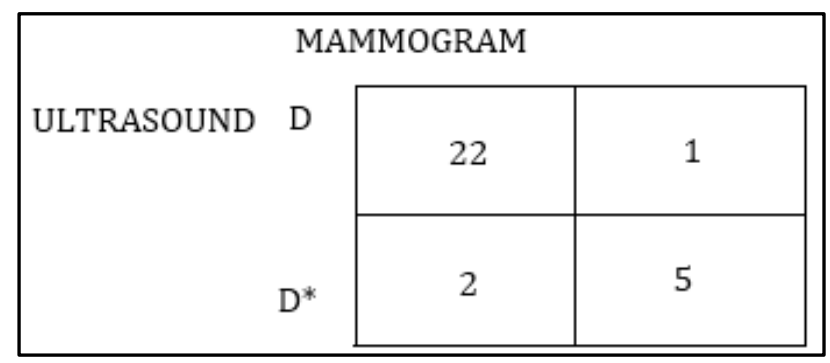

\begin{tabular}{|c|c|}
\hline Sensitivity & $92 \%$ \\
\hline Specificity & $83 \%$ \\
\hline Positive Predictive Value & $96 \%$ \\
\hline Negative Predictive Value & $71 \%$ \\
\hline Accuracy & $90 \%$ \\
\hline Prevalence Pretest Probability & $80 \%$ \\
\hline
\end{tabular}

Comparative Analysis

\begin{tabular}{|c|c|c|}
\hline \multirow[b]{2}{*}{ ULTRASOUND } & \multicolumn{2}{|c|}{ CYTOLOGY } \\
\hline & 22 & 3 \\
\hline $\mathrm{D}^{*}$ & 4 & 3 \\
\hline \multicolumn{2}{|c|}{ Sensitivity } & $83 \%$ \\
\hline \multicolumn{2}{|c|}{ Specificity } & $50 \%$ \\
\hline \multicolumn{2}{|c|}{ Positive Predictive Value } & $87 \%$ \\
\hline \multicolumn{2}{|c|}{ Negative Predictive Value } & $42 \%$ \\
\hline \multicolumn{2}{|c|}{ Accuracy } & $77 \%$ \\
\hline \multicolumn{2}{|c|}{ Prevalence Pretest Probability } & $80 \%$ \\
\hline
\end{tabular}

Comparative Analysis

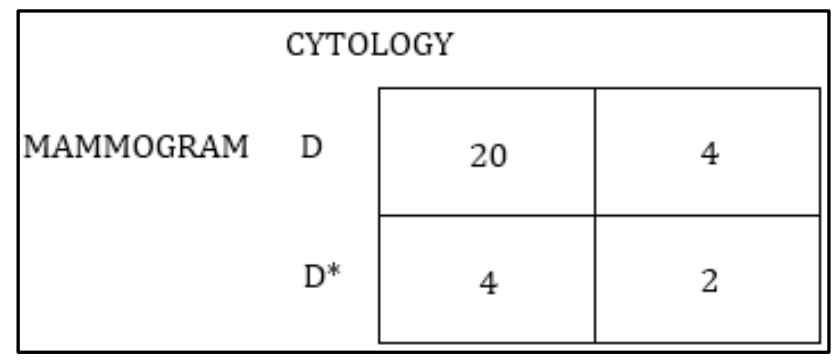

\begin{tabular}{|c|c|}
\hline Sensitivity & $83 \%$ \\
\hline Specificity & $33 \%$ \\
\hline Positive Predictive Value & $83 \%$ \\
\hline Negative Predictive Value & $33 \%$ \\
\hline Accuracy & $73 \%$ \\
\hline Prevalence Pretest Probability & $80 \%$ \\
\hline
\end{tabular}


Comparative Analysis

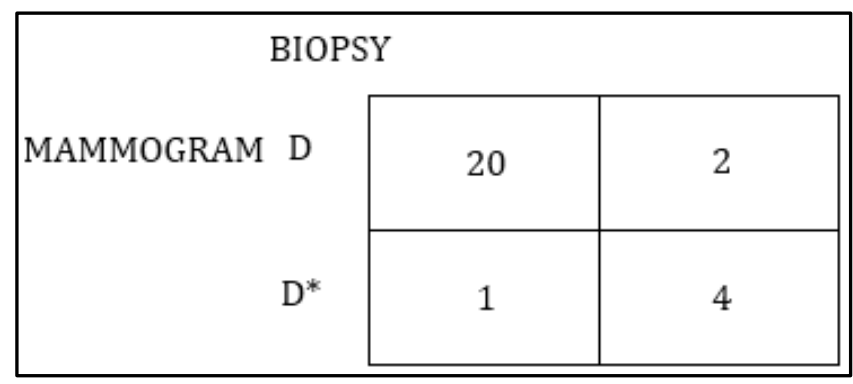

\begin{tabular}{|c|c|}
\hline Sensitivity & $95 \%$ \\
\hline Specificity & $67 \%$ \\
\hline Positive Predictive Value & $91 \%$ \\
\hline Negative Predictive Value & $80 \%$ \\
\hline Accuracy & $89 \%$ \\
\hline Prevalence Pretest Probability & $78 \%$ \\
\hline Pretest Probability Positive Result & $91 \%$ \\
\hline Pretest Probability Negative Result & $25 \%$ \\
\hline
\end{tabular}

Comparative Analysis

\begin{tabular}{|c|c|c|}
\hline \multicolumn{3}{|c|}{ BIOPSY } \\
\cline { 2 - 3 } CYTOLOGY D & 17 & 3 \\
\cline { 2 - 3 } D $^{*}$ & 3 & 3 \\
\hline
\end{tabular}

\begin{tabular}{|c|c|}
\hline Sensitivity & $85 \%$ \\
\hline Specificity & $50 \%$ \\
\hline Positive Predictive Value & $85 \%$ \\
\hline Negative Predictive Value & $50 \%$ \\
\hline Accuracy & $77 \%$ \\
\hline Prevalence Pretest Probability & $77 \%$ \\
\hline Pretest Probability Positive Result & $85 \%$ \\
\hline Pretest Probability Negative Result & $50 \%$ \\
\hline
\end{tabular}

\section{Comparative Analysis}

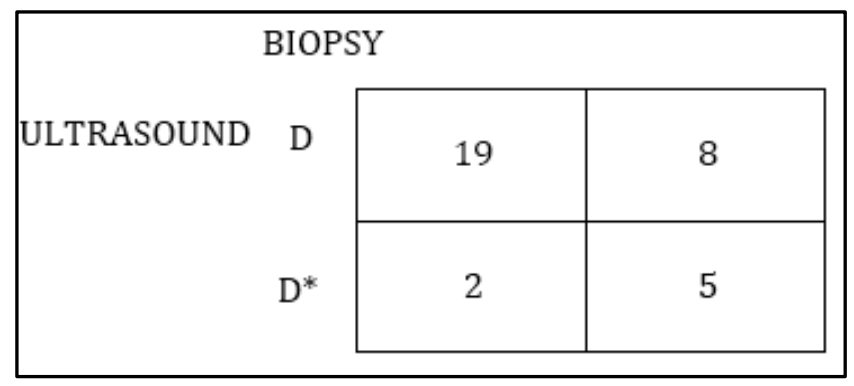

\begin{tabular}{|c|c|}
\hline Sensitivity & $90 \%$ \\
\hline Specificity & $38 \%$ \\
\hline Positive Predictive Value & $70 \%$ \\
\hline Negative Predictive Value & $71 \%$ \\
\hline Accuracy & $71 \%$ \\
\hline Prevalence Pretest Probability & $62 \%$ \\
\hline Pretest Probability Positive Result & $70 \%$ \\
\hline Pretest Probability Negative Result & $29 \%$ \\
\hline
\end{tabular}

Comparative Analysis

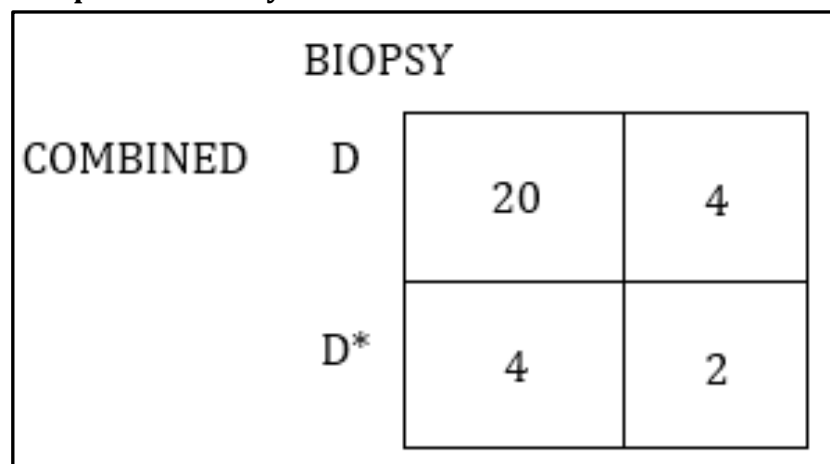

\begin{tabular}{|c|c|}
\hline Sensitivity & $96 \%$ \\
\hline Specificity & $83 \%$ \\
\hline Positive Predictive Value & $96 \%$ \\
\hline Negative Predictive Value & $83 \%$ \\
\hline Accuracy & $94 \%$ \\
\hline
\end{tabular}

\section{EVALUATION OF THE RESULTS}

\begin{tabular}{|c|c|c|c|}
\hline & Sensitivity & Specificity & Accuracy \\
\hline Mammogram & $95 \%$ & $67 \%$ & $89 \%$ \\
\hline Ultrasonogram & $90 \%$ & $40 \%$ & $70 \%$ \\
\hline Cytology & $85 \%$ & $50 \%$ & $77 \%$ \\
\hline Combined & $96 \%$ & $83 \%$ & $94 \%$ \\
\hline
\end{tabular}

Hence, by evaluating the test by using a combined modality the specificity of the test and accuracy gets improved.

\section{CONCLUSION}

The primary objective of a Breast Cancer Clinic is to maximize cancer detection whilst minimizing the number of unnecessary benign surgical biopsies.

The triple assessment of symptomatic breast lesions is the mainstay of modern breast diagnosis. Clinical examination requires experience to distinguish benign from malignant.

Breast imaging has an extremely important role in deciding whether an abnormality is present or not and its likelihood of malignancy. Each of the components of the triple assessment has its own limitations. It is therefore essential for a safer patient management that interpretation is undertaken by multidisciplinary team, so that accuracy of each component is known.

Mammogram has a good diagnostic yield in detection of breast lesions. Ultrasonogram can be used as a single modality in patients who are less than 30 years of age, in pregnant and lactating females as it does not employ ionizing radiation. Breast density does not limit its use in ultrasound.

In this study, the sensitivity of the mammogram is $95 \%$ in detecting lesions and the specificity is $67 \%$ giving an accuracy of $90 \%$. The sensitivity of USG is $90 \%$ and specificity is only $40 \%$ giving an accuracy of $70 \%$. Cytology has a sensitivity of $85 \%$ and specificity of $50 \%$ and the accuracy is $77 \%$. With the combined modality, the sensitivity is $96 \%$ and the specificity is $83 \%$ and accuracy is $94 \%$.

The gold standard of symptomatic breast diagnosis for more than a decade has been clinical examination, needle biopsy and imaging studies. This study analyses the place of mammogram and shows that the resultant sensitivity is extremely high, but it must be used in conjunction with USG 
and needle biopsy to achieve a satisfactory specificity and to avoid unnecessary benign surgical biopsies.

\section{REFERENCES}

1. Clarke D, Sudhakaran N, Gateley CA. Replace fine needle aspiration cytology with automated core biopsy in the triple assessment of breast cancer. Ann R Coll Surg Engl 2001;83(2):110-2.

2. Schoonjans JM, Brem RF. Fourteen-gauge ultrasonographically guided large-core needle biopsy of breast masses. J Ultrasound Med 2001;20(9):967-72.

3. Morris KT, Vetto JT, Petty JK, et al. A new score for the evaluation of palpable breast masses in women under age 40. Am J Surg 2002;184(4):346-7.

4. Wendie A Berg, Lorena Gutierrez, Moriel S, et al. Diagnostic accuracy of mammography, clinical examination, US, and $\mathrm{mr}$ imaging in preoperative assessment of breast cancer. Radiology 2004;233(3):830-49.

rsnajnls.org/cgi/content/abstract/233/3/830.

5. Kerlikowske K, Smith-Bindman R, Ljung BM, et al. Evaluation of abnormal mammography results and palpable breast abnormalities. Ann Intern Med 2003;139(4):274-84.

6. Pande AR, Lohani B, Sayami P, et al. Predictive value of ultrasonography in the diagnosis of palpable breast lump. Kathmandu Univ Med J 2003;1(2):78-84.

7. Fajardo LL. Screening mammography, sonography of dense fibrocystic breast tissue. AJR Am J Roentgenol 2003;181(6):1715-15.

8. Dennis MA, Parker SH, Klaus AJ, et al. Breast biopsy avoidance: the value of normal mammograms and normal sonograms in the setting of a palpable lump. Radiology 2001;219(1):186-191.
9. Weinstein SP, Conant EF, Orel SG, et al. Retrospective review of palpable breast lesions after negative mammography and sonography. J Women's Imaging 2000;2:15-18.

10. Shetty MK, Shah YP, Sharman RS. Prospective evaluation of the value of combined mammographic and sonographic assessment in patients with palpable abnormalities of the breast. J Ultrasound Med 2003;22(3):263-8.

11. Kumle M, Weiderpass E, Braaten $\mathrm{T}$, et al. Use of oral contraceptives and breast cancer risk: the norwegianswedish women's lifestyle and health cohort study. Cancer Epidemiol Biomarkers Prev 2002;11(11):137581.

12. Budai B, Szamel I, Sulyok Z, et al. Characteristics of cystic breast disease with special regard to breast cancer development. Anticancer Res 2001;21(1B):749-52.

13. Barton MB, Harris R, Fletcher SW. The rational clinical examination does this patient have breast cancer? the screening clinical breast examination: should it be done? How? JAMA 1999;282(13):1270-80.

14. Obenauer S, Luftner-Nagel S, von Heyden D, et al. Screen film vs. full-field digital mammography: image quality, detectability and characterization of lesions. Eur Radiol 2002;12(7):1697-702.

15. Lewin JM, Hendrick RE, D'Orsi CJ, et al. Comparison of full-field digital mammography with screen-film mammography for cancer detection: results of 4,945 paired examinations. Radiology 2001;218(3):873-80. 